Miroslav Vaněk

[Praga, Republika Czeska]

\title{
Czeska oral history w perspektywie globalnej. Podobieństwa i różnice ${ }^{1}$
}

Czeska oral history (podobnie jak oral history w innych krajach postkomunistycznych) nie doświadczyła owego pionierskiego czy, lepiej rzecz ujmując, założycielskiego etapu przypadającego na lata 6o. i 7o., kiedy na świecie można mówić nie tyle o metodzie, ile o swego rodzaju ruchu społecznym, którego celem było „oddolne” przybliżanie historii.

W latach sześćdziesiątych, przede wszystkim w USA, do głosu doszła pełna ambicji grupa badaczy oral history ${ }^{2}$. Określili oni źródła ustne jako równorzędne ze źródłami pisanymi, a co więcej, przeszli do ofensywy na polu społecznym. W kontekście ówczesnych wydarzeń w USA: walki o prawa

1 Niniejszy tekst powstał w ramach projektu grantowego: GA ČR Česká společnost v období tzv. Normalizace a transformace: životopisná interview, č. P 410/11/1352.

2 W USA za założycieli oral history uznawani są Allan Nevins (1890-1971), późniejszy uniwersytecki profesor historii, i jego uczeń Louis M. Starr (1917-1980). Obaj brali udział w powołaniu pierwszego centrum oral history przy University of Columbia (Columbia Oral History Office) w Nowym Jorku. Do 1960 r. centrum udostępniło 16o ooo stron zapisów rozmów, w roku 1983 był to już 1 milion 400 tysięcy stron. Centrum posłużyło jako wzór dla innych podobnych instytucji, które na terenie Stanów Zjednoczonych zaczęły wyrastać dosłownie jak grzyby po deszczu: w 1965 r. było takich centrów 89, dwanaście lat później (1977) ich liczba sięgała prawie tysiąca. 
obywatelskie Afroamerykanów oraz prawa kobiet, imigrantów i innych mniejszości, oral history pojawiła się z jasno zadeklarowanym celem, by oddać głos wykluczonym społecznie, tzn. grupom, które przez długie dziesięciolecia, a nawet stulecia, były pomijane w oficjalnych narracjach historycznych. Chcąc nie chcąc, oral history stała się narzędziem budowania tożsamości grup zmarginalizowanych i transformacji społecznej. W tamtej epoce oral history bardziej niż dyscypliną naukową, była walczącym ruchem społecznym, niekiedy wręcz militarnym. Nie należy się więc dziwić, że środowisko akademickie, a szczególnie środowisko historyków, nie przyjęło jej z otwartymi ramionami. W tamtym okresie oral history wyróżniała się dużym nonkonformizmem, który rezonował z ruchem obywatelskim drugiej połowy lat sześćdziesiątych, najpierw w USA, a później także w Europie Zachodniej. Najbardziej radykalne frakcje broniły historii alternatywnej nie tylko w relacji ze światem akademickim, lecz także ze wszystkimi konstrukcjami historiograficznymi budowanymi na bazie dokumentów pisanych. W wielu kręgach społecznych tamtego okresu mocno oddziaływał pogląd, który źródła ustne uznawał za „prawdę ludu”.

Skutkiem tych działań było powołanie w 1966 r. na kontynencie amerykańskim pierwszego Towarzystwa Historii Mówionej (Oral History Association). Wyraźna zmiana jakościowa nastąpiła w 1973 r., kiedy znany badacz oral history Ronald Grele, na spotkaniu Organizacji Historyków Amerykańskich w Chicago, wysunął nowe propozycje badawcze: postulował, aby oral history koncentrowała się niemal wyłącznie na historiach ludzi „wykluczonych”, tzn. obywateli pozostających poza zainteresowaniem „wielkiej historii". Ta koncepcja, by zwrócić oral history ku grupom wykluczonym, została przyjęta w tamtym czasie także w innych krajach. W Anglii w 1971 r. powstało Towarzystwo Historii Mówionej (Oral History Society) wydające własne czasopismo „Journal of the Oral History Society”. Duże znaczenie dla całej społeczności badaczy oral history miała książka Paula Thompsona The Voices of the past. Owa „biblia” oral history umocniła pogląd, że jedną z ważnych funkcji oral history jest przywrócenie historii ludziom i dążenie do demokratyzacji interpretacji historii. Według wielu, oral history miała prezentować się jako swego rodzaju kontrhistoria, prowokująca, czasem wręcz radykalnie, historię pisaną tradycyjnie. Debata na temat oral history stopniowo rozszerzała się na kolejne kraje: Niemcy, Włochy, Francję i Hiszpanię. Wszędzie tam nabierała specyficznych cech w zetknięciu z miejscową kulturą. Mimo początkowego sceptycyzmu ruch oral history wzmacniał się także w europejskiej społeczności akademickiej. Stało się tak bezsprzecznie przede wszyst- 
kim dzięki rozprawom naukowym Paula Thompsona, ale także wielu innych autorów, takich jak Luisa Passerini, Alessandro Portelli, Mercedes Vilanova, Lutz Niethammer czy Alexander von Plato.

Z pewną znajomością rzeczy mogę stwierdzić, że wyżej opisane zaangażowanie zwolenników oral history było w początkowym okresie na pewno potrzebne i miało swoje uzasadnienie. Zwrócono wówczas uwagę na grupy nieuprzywilejowane (polityczne, narodowościowe), na problematykę kobiecą itd. Bez tej społeczno-politycznej aktywności w tamtym konkretnym czasie wyżej wspomniane tematy nie znalazłyby się w centrum zainteresowania „wielkiej” historii i „wielkich” historyków.

W latach 70. i 80. w Republice Czeskiej (podobnie jak w innych krajach bloku socjalistycznego) oral history była po prostu nieznana, a tamtejsi historycy „nie spotkali się” z nią. Pojedyncze próby wykorzystania świadectw w publikacjach naukowych, jako coś więcej niż tylko ilustrację, nie przyniosły znaczących efektów. Działo się tak z powodu dostosowywania tematyki badawczej do potrzeb ideologicznych, nieznajomości metodologii (braku ujednoliconej metodologii zbierania i katalogowania informacji, przenikania się rozmów prowadzonych „twarzą w twarz” z tzw. spotkaniami/zebraniami ze świadkami), braku analiz i interpretacji uzyskanych informacji. Nie znano zagadnień etyki prowadzenia wywiadu, nie były też ustalone zasady zachowywania autentycznego zapisu. Brakowało zaawansowanych technik utrwalania relacji i możliwości profesjonalnego archiwizowania danych. Praca ze świadkami historii z wielu powodów tylko trochę przypominała tam oral history.

W tym kontekście często stawiam sobie hipotetyczne pytanie: czy gdyby oral history była znana wcześniej w naszym czeskim środowisku i w innych autorytarnych reżimach, to czy mogłaby odegrać pozytywną rolę i stać się swego rodzaju narzędziem bojowego zaangażowania społeczno-politycznego, zgodnie z tezami A. Freunda ${ }^{3}$ i A. Thomsona ${ }^{4}$, a także szeregu innych postulujących niezależne badania w Afryce, Ameryce Łacińskiej, a do czasu upadku gen. Franco także w Hiszpanii?

3 A. Freund, Oral history in Canada. A Paradox, [w:] Canada in Grainau: A Multidisciplinary Survey after 30 Years / Le Canada à Grainau: un survol multidisciplinaire 30 ans après, red. K.-D. Ertler, H. Lutz, Frankfurt am Main-Berlin-Bern-New York-Oxford-Wien 2009, s. 305-335.

4 A. Thomson, Four paradigm transformations in oral history, „Oral History Review (USA)", vol. 34 (2007), nr 1, s. 49-70. 
Czeska historiografia byłaby bez wątpienia bogatsza, gdyby retrospektywny przegląd naszych badań oral history przed 1989 r. można było zacząć, odnosząc się do rodzimych naukowych i niezależnych badań historycznych, poświęconych np. proskrybowanym grupom - dysydentom lub więźniom sumienia. Jednak takich badań nie przeprowadził niestety żaden z historyków czeskich przed 1989 r. Nieobecność oral history w oficjalnej historiografii przed 1989 r. jest zrozumiała ze względu na reżim autorytarny, który uniemożliwiał prowadzenie niezależnych badań historycznych i socjologicznych. Zaskakuje jednak, że apel o badanie proskrybowanych grup metoda oral history nie został wystosowany ani przez środowiska historyków działających w podziemiu, ani nawet za granicą, dokąd emigrowało lub było zmuszonych emigrować wielu badaczy po 1968 r. i gdzie metoda ta była już od lat z sukcesem wykorzystywana ${ }^{5}$. Przypuszczam, że $\mathrm{w}$ tym czasie czescy historycy działający za granicą, w przeciwieństwie do historyków działających w kraju, przynajmniej o oral history słyszeli.

Z powyższego wynika, że starsze pokolenie historyków, zarówno w kraju, jak na emigracji (z nielicznymi wyjątkami), nie doceniało wartości metody oral history. Historycy czechosłowaccy (jako całość), jakby nie zauważyli trendu lat osiemdziesiątych, kiedy w związku z podaniem w wątpliwość pozytywistycznego pojęcia obiektywizmu naukowca doszło do zmian w podejściu do badań historycznych: studia nad nowymi tematami mocno akcentowały konieczność prowadzenia badań jakościowych, które w ten sposób znowu zyskały na znaczeniu. Po raz kolejny „odkryto” osobiste doświadczenie, zainteresowanie badaczy odeszło od opisu, podkreślano znaczenie osobistego przeżycia i wyjątkowości sytuacji indywidualnej ${ }^{6}$.

Faktem pozostaje, że czeska historiografia rozpoczęła badania nad nieuprzywilejowanymi grupami obywateli dopiero po 1989 r. i w związku

5 O ile metoda oral history w Europie Zachodniej i USA ugruntowała się z sukcesem już w latach sześćdziesiątych, o tyle za początek etapu umiędzynarodawiania oral history uznać należy lata siedemdziesiąte, kiedy powstało wiele pracowni oral history. Przyznać należy, że na tym etapie rozwoju większość badaczy pochodziła nadal z Europy Zachodniej i USA, a hegemonia ta miała wpływ także na lokalizację kolejnych konferencji międzynarodowych, które odbywały się wyłącznie w krajach Europy Zachodniej.

6 Zob. A. Thomson, Dancing through the memory of our movement: Four paradigmatic revolutions in Oral History. Tekst dostępny na stronie http://www.ohaansw.org.au/ (dostęp: 21 VI 2013 r.). 
z tym przegapiony został moment, kiedy badania te mogły zyskać miano niezależnych, zaangażowanych czy „bojowych”, i których wartość nie byłaby podawana w wątpliwość.

W Republice Czeskiej metoda oral history zaczęła być wykorzystywana dopiero w połowie lat 90., ale o jej rozkwicie możemy mówić dopiero w ostatnich sześciu, ośmiu latach, kiedy to, wedle słów południowoafrykańskiego badacza oral history Seana Fielda, z metody lekceważonej i krytykowanej, stała się ona w końcu metodą respektowaną ${ }^{7}$ W ostatnich trzech, czterech latach można mówić nawet o boomie oral history w Republice Czeskiej, chociaż nadal nie w takim wymiarze, jak ma to miejsce w Ameryce Południowej i Północnej czy w RPA ${ }^{8}$.

Zwiększone zainteresowanie oral history przynosi dosyć oczywistą satysfakcję, a może nawet swego rodzaju poczucie zadośćuczynienia wszystkim, którzy od lat starają się o jej rozpowszechnianie i praktyczne wykorzystanie. Jednak z pewnością nie należy spoczywać na laurach. Pojawiają się problemy, które są związane przede wszystkim z właściwym zrozumieniem metody oral history i z utożsamieniem się jej z założeniami. Za takie uważam zarówno zasady etyczne, jak i metodologiczne, inaczej mówiąc: rzemieślniczo opanowaną metodologię i znajomość kontekstu, jako konieczny warunek wartościowej interpretacji historycznej.

Podobnie jak Sean Field stawiam sobie pytanie, czy trend, którego jesteśmy w ostatnich latach świadkami także u nas, jest jednoznacznie pozytywny. Szukam odpowiedzi na pytanie, co było przyczyną tego zwrotu, staram się dostrzec niebezpieczeństwa i rafy, na jakie możemy się natknąć w związku z ciągłym rozwojem tego trendu. Patrzę na zagadnienie z punktu widzenia historyka dziejów najnowszych, który poznał różne nurty oral history (akademickiej i amatorskiej) i ich wykorzystanie w różnych dziedzinach i dyscyplinach, także w kontekście międzynarodowym.

Dzieje najnowsze są przestrzenią spotkania badań naukowych z osobistymi przeżyciami i doświadczeniami uczestników wydarzeń, którzy są posiadaczami własnej pamięci i wspomnień o danym okresie, ewentualnie są narratorami osobistych opowieści i wyobrażeń o niedawnej historii. Dzieje najnowsze, jako epoka historyczna, nie należą bowiem jedynie do

7 S. Field, From stepchild to elder. Has oral history become „respectable”?, http://www. iohanet.org/debate/index.php (dostęp: 21 VI 2013 r.).

8 Ibidem. 
specjalistów-historyków. W tworzeniu ich obrazu mogą brać też udział laicy, ponieważ także oni pamiętają. Należy więc z pewnością mówić o demokratyzacji historii, która jednak może prowadzić, przyznajmy to, do dyletanctwa i upraszczania historii, ponieważ każde wspomnienie jest efektem indywidualnej perspektywy spojrzenia w przeszłość. Czy ta sytuacja nie prowadzi jednak do odrzucenia historii krytycznej na korzyść popularnego, zindywidualizowanego wspominania i opowiadania? Czy w efekcie łatwo dostępna pamięć nie przyćmi specjalistycznych, krytycznych przekazów o przeszłości?

To dobrze, że podczas naszych konferencji, warsztatów, a także nieoficjalnych spotkań możemy dyskutować o tych kwestiach. Przypuszczam, że nie tylko ja, ale większość spośród tych, którzy głębiej interesują się oral history i którzy tę metodę wykorzystują w praktyce, odrzuciłaby wyżej wspomniane "popularne i uproszczone” perspektywy i, co więcej, do znudzenia wciąż powtarzałaby, że oral history jest tylko jedną z wielu metod przybliżenia i rozumienia naszej historii, zwracałaby przy tym uwagę na konieczność badania źródeł pisanych, znajomość kontekstu, jak również świadomość siły i wagi interpretacji. Niestety można niekiedy odnieść wrażenie, że wszelkie nasze wysiłki idą na marne i nie znajdują zrozumienia, a dyskusje przebiegają według wcześniej znanych i niezmiennych schematów (powtarzająca się dyskusja o subiektywności źródła oral history czy o problematyce ludzkiej pamięci). W każdej dyscyplinie dyskusje poglądowe, w ramach których ścierają się różne punkty widzenia na ten czy ów problem, są zjawiskiem pozytywnym. Tak samo jest w przypadku oral history, ale jedynie przy założeniu, że obie strony znają swoje wzajemne stanowiska, że dyskutujący zaznajomili się z opublikowaną dotąd w kraju i za granicą literaturą, a swoich twierdzeń nie opierają na domniemaniach. Wraz z nadejściem nowego pokolenia historyków, kompetentnych zarówno od strony teoretycznej, jak i metodologicznej, sytuacja czeskiej oral history zbliżyła się do standardów znanych wcześniej na Zachodzie.

Niebezpieczeństwa dla współczesnej czeskiej oral history, dostrzegałbym na przykład, podobnie jak austriaccy koledzy Alex Lichtblau czy Mario Bohm, głównie w upraszczającym podejściu dziennikarsko-populistycznym czy specyficznej perspektywie dokumentacyjnej, podającej się za oral history (co więcej, często motywowanej ideologicznie). Jasne jest, że jeżeli chodzi o zaangażowanie ideologiczne, będzie to już zupełnie inne zaangażowanie niż to, które pomogło uformować metodę w latach 6o. i 70. Działalność „samozwańczych” badaczy oral history, którzy poza wykorzy- 
staniem nazwy oral history nie mają z metodą nic wspólnego, może być niebezpieczna nie tylko zresztą w środowisku czeskim. W ostatecznym rozrachunku taka nieprofesjonalna działalność może okazać się szkodliwa i prowadzić nawet do całkowitej destrukcji instytucji i stowarzyszeń, które profesjonalnie i rzetelnie zajmują się oral history. O ile dyskusja ze starszym pokoleniem historyków doprowadziła wielu z nas do rzeczywiście krytycznej oceny źródeł powstałych w ramach badań oral history, o tyle dyskusja o związku oral history z dziennikarstwem i publicystyką, a także dziennikarską dokumentalistyką, jest, jak się wydaje, dopiero przed nami.

Jaka jest ogólna relacja między oral history a dziennikarstwem? Należy wyjść od podstawowej przesłanki: media z zasady nie są dyscypliną naukową. Media i nauka funkcjonują na różnych poziomach, mają swoje metody pracy, swoje „grupy docelowe”. Media, poza wyjątkami, muszą informować, bawić, relacjonować, muszą wywoływać u widzów emocje, ale nie zawsze muszą analizować. W nauce natomiast chodzi o wyjaśnianie i sprzeczności. Nauka powinna być odporna na naciski czy krytykę ze strony mediów (biorących często publiczność jako poręczyciela), oskarżających, że np. nie dostarcza wystarczającej liczby bohaterów, że wyniki badań nie są dostatecznie jednoznaczne, że nauka nie zajmuje się tematami ważkimi, to znaczy tymi, które za ważkie zostały uznane przez media. Co więcej szereg publicystów oczekuje od nauki dokładnej i jednoznacznej interpretacji, najlepiej w formie wyroku. Wielu publicystów kwestionuje pogląd, że rezultaty prac naukowych są z zasady inne, niż skutki prawne, że dotyczą tylko określonego kontekstu, że są tymczasowe, paralelne z innymi wyjaśnieniami, prawdopodobne itd. A mimo to dziennikarze w wielu przypadkach nie mają wątpliwości, że to właśnie oni uprawiają prawdziwą oral history.

Czy projekty dziennikarskie są zatem szansą czy zagrożeniem dla oral history? Na tę kwestię należy patrzeć dialektycznie, ponieważ działalność dziennikarską na wysokim poziomie możemy traktować jak reklamę historii i aktywność ogólnie rzecz biorąc pożyteczną dla obu światów - nauki i publicystyki. Mówiąc o wysokim poziomie, mam na myśli wartościowe projekty, wartościową współpracę, kompetentnie zastosowane metody. Co to oznacza? Jak kompetencję w dziedzinie oral history rozumiemy my, profesjonalni badacze? Najprościej to wyjaśnić na przykładach negatywnych. Jak więc nie postępować i co według naszych standardów nie zalicza się do oral history?

Rozmowy ze świadkami nie powinny być wykorzystywane jako „ozdoba”. Własnych tez nie należy uzasadniać relacją świadka, sprytnie zmontowaną w taki sposób, aby potwierdzała odgórne założenie autora. Publikowaną 
rozmowę traktuje się ponadto jako drobny fragment historii życia narratora. Konkretnego fragmentu nie prezentujemy jako historycznej rzeczywistości. Nie demonizujemy poszczególnych osób, nie wydajemy surowych i uproszczonych osądów, odpowiednich raczej dla baśniowej krainy Dobra i Zła.

W ostatnim czasie z zaniepokojeniem śledzę niektóre próby opracowywania „pamięci” przez laików czy różne „towarzystwa pamięci”. Ich inicjatywy prowadzą często w bardzo niewłaściwym kierunku, są wyjęte z kontekstu i - co nie mniej istotne - również zabarwione ideologicznie: promują obowiązującą obecnie także w czeskiej przestrzeni ideologię neoliberalną. Jak inaczej można rozumieć założenia niektórych projektów, których autorzy już od samego początku przygotowują swe publikacje ze z góry ustaloną „polityczną tezą”, na przykład, że „w minionym reżimie nie było w ogóle nic dobrego, a jeżeli coś było, to wbrew reżimowi”. Oczywiście, nie jest moim zamiarem obrona minionego reżimu (!), zadziwia mnie jednak naiwność, czy krótka pamięć niektórych protagonistów tego ahistorycznego podejścia. Podobnie, jak już wspomniano, postępował wcześniej właśnie ten krytykowany reżim autorytarny. Jak wielu moich kolegów, stawiam zatem pytanie, jak się zmierzyć, czy jak odbierać projekty i akcje takie jak Hlasy hrdinü ${ }^{9}$, wystawy Tváře moci ${ }^{10}$, inicjatywy Post Bellum ${ }^{11}$ czy Př́běhy 20. století ${ }^{12}$. Czy chodzi tu o inicjatywy, które stawiają sobie za cel

9 Hlasy hrdinů, projekt zbierania świadectw historycznych, który stał u początków inicjatywy Post Bellum. W latach 2001-2006 zgromadzono ponad 6oo wywiadów ze świadkami i uczestnikami wydarzeń znaczących dla przedwojennej i powojennej Czechosłowacji. W 2006 r. materiały te weszły do zasobu archiwum internetowego Pamět’ národa (http://www.pametnaroda.cz) (przyp. tłum.).

10 Tváře moci, wystawa przygotowana przez Ústav pro studium totalitních režimů w 2008 r., przedstawiająca sylwetki 28 przedstawicieli służb bezpieczeństwa (Sbor národní bezpečnosti, Státní bezpečnost) z lat 1948-1989 z Pragi i kraju środkowo czeskiego. (http://www.ustrcr.cz/cs/vystava-tvare-moci-v-praze) (przyp. tłum.).

11 Post Bellum (http://www.postbellum.cz), pozarządowa organizacja pożytku publicznego, założona w 2001 r. przez dziennikarzy i historyków. Zajmuje się zbieraniem wspomnień i pamiątek z czasów II wojny światowej i reżimu komunistycznego, a także udostępnianiem ich opinii publicznej w archiwum internetowym Pamět' národa (http://www.pametnaroda.cz) (przyp. tłum.).

12 Př́běhy 2o. století, cykliczny dokumentalny program radiowy (autorzy: Mikuláš Kroupa i Adam Drda), realizowany przez publiczną rozgłośnię Český rozhlas - Rádio Česko we współpracy z Post Bellum, przedstawiający losy bohaterów wojennych, byłych więźniów politycznych, działaczy podziemia, ofiar łagrów radzieckich i obozów nazistowskich, dysydentów, a także tych z „drugiej strony”: Służby Bezpieczeństwa, KGB, wywiadu i kontrwywiadu wojskowego, http://www.postbellum.cz/cz/ pribehy-2o-stoleti/pribehy-2o-stoleti.aspx (przyp. tłum.). 
jedynie zbieranie, archiwizowanie i organizowanie pamięci indywidualnej czy też o inicjatywy formujące pamięć indywidualną i zbiorową? I jaki jest udział tej „zorganizowanej” pamięci w „oczyszczaniu przeszłości” czy też w jej badaniu?” Czy nie nadszedł czas dokładnego przeanalizowania tych inicjatyw z perspektywy polityki pamięci czy polityki historycznej?

Aktualną, ciągle powracającą kwestią jest odnalezienie owego pożądanego punktu przecięcia tak różnych światów, jakimi są dziennikarstwo odwołujące się często do emocji i nauka zdecydowanie się od emocji odcinająca, wzbraniająca się przed wywoływaniem zakłopotania czy wzburzenia. Nie chodzi przy tym jedynie o tę podstawową zasadę, odmienna jest także sama metoda prowadzenia rozmów biograficznych. Badacze oral history są często powściągliwi, szanują tabu czy pewną niechęć narratora do mówienia o niektórych wydarzeniach, zachowują się bardzo uważnie i empatycznie. Wielu dziennikarzy takiego „miękkiego” zachowania nie rozumie, zdarza się, że je nawet krytykują. Sami są bowiem na studiach przygotowywani i wychowywani do zadawania pytań na drażliwe tematy. Typowy jest dla nich styl twardszy, metoda konfrontacyjna i prowokująca. Nie wiem, w jakim stopniu na uczelniach są im wyjaśniane i zaszczepiane kwestie etyczno-moralne, a więc kwestie, które dla kompetentnych badaczy oral history są oczywistością. Czy adepci rzemiosła dziennikarskiego zastanawiają się nad tym, co dzieje się po drugiej stronie stołu, jak czują się narratorzy poddani tak dziś modnemu pressingowi, poważnie wyeksploatowani (dosł. do totalnej eksploatacji), którzy podczas krótkiego pożegnania słyszą, że ich wypowiedź będzie „jakoś” opracowana, ale że oni, narratorzy, muszą dobrze rozumieć, że rozmowy nie da się oczywiście opublikować w całości? Nie wiem. Nie wiem także, czy zainteresowani zdają sobie sprawę z tego, że „twardszą metodą” zdecydowanie wpływają na przebieg rozmowy. Jeśli nie znajdzie się to w analizie i w ocenie rozmowy - uważam to za poważny błąd.

W naszych warunkach nie poświęca się dostatecznej uwagi kwestiom etyki i prawodawstwa, w przeciwieństwie np. do Europy Zachodniej, Ameryki Północnej i Australii, gdzie obowiązują dosyć jasne zasady etyczne i prawne. Ustalenie zasad etycznych jest uznawane za kluczowy czynnik, konieczny nie tylko do utrzymania projektu badawczego, lecz także do stworzenia podstaw do relacji prawnej, zarówno między pytającym (instytucją) a narratorem, jak i między pytającym a jego pracodawcą czy ewentualnymi sponsorami. Co więcej, stosowanie się do nich gwarantuje kontynuację badań. Obecnie międzynarodowe środowisko badaczy oral history kieruje się w swojej działalności zasadami dwóch organizacji Międzynarodowego Towarzystwa Historii 
Mówionej (International Oral History Association - IOHA) i Amerykańskiego Towarzystwa Antropologicznego (American Anthropological Association - AAA).

Jak głosi akt erekcyjny Międzynarodowego Towarzystwa Historii Mówionej $^{13}$, oral history jest metodą używaną do dokumentowania ludzkiego doświadczenia za pośrednictwem nagrywanych rozmów, która wymaga respektowania jasnych zasad etycznych. W tym zakresie IOHA wykorzystuje przede wszystkim kodeksy etyczne konkretnych towarzystw narodowych. Za najważniejszy uznać można tekst Principles and Standards Amerykańskiego Towarzystwa Oral History ${ }^{14}$, kodeks etyczny Oral History Society University of Essex ${ }^{15}$ czy Australijskiego Towarzystwa Oral History ${ }^{16}$. Ich wspólnym celem jest ograniczenie niewłaściwej metodologii prowadzenia rozmów, wyłączenie manipulacji i zniekształcania historii, nadużywania danych osobowych i pozyskanych informacji w ogóle.

Jedną z najważniejszych zasad etycznych przy prowadzeniu badań oral history jest szacunek wobec narratora, jako dawcy swojej historii życia. Pytający, jako specjalista i przedstawiciel świata nauki, w żadnym przypadku i w żadnym momencie wywiadu nie może prowadzić rozmowy z zamiarem manipulacji.

Niestety, tak samo jak w innych krajach postkomunistycznych, także i u nas spotykamy się z poważnym łamaniem zasad czy z niedostatecznym szacunkiem wobec narratora - „dawcy” historii. Stosunkowo często zachowują się tak czescy dziennikarze, czy - jak sami siebie nazywają dokumentaliści. Spotkaliśmy się sami z oburzającymi przypadkami, kiedy dziennikarze - „dokumentaliści” nie tylko nie do końca informowali swoich narratorów o właściwych celach, dla których się z nimi skontaktowali, ale niezgodnie z początkową umową (jeśli taka była) rozporządzali uzyskanymi wywiadami bez pisemnej zgody narratorów. Dla każdego, kto miał styczność z oral history, jest oczywiste, że udostępnienie wywiadu jest tematem bardzo delikatnym i doniosłym. Zwłaszcza tam, gdzie cho-

13 http://www.ioha.fgv.br/ioha/english/7-o6revIOHAConstEng.doc (dostęp: 21 VI 2013 r.).

14 Zob. OHA Evaluation Guidelines. http://www.oralhistory.org/about/principles-and-practices/oral-history-evaluation-guidelines-revised-in-200o/\#1.3 (dostęp: 21 VI 2013 r.).

15 http://www.ohs.org.uk/ethics/index.php (dostęp: 21 VI 2013 r.).

16 http://www.ohaa.net.au/guidelines.htm (dostęp: 21 XI 2011 r.). Na podstawie obu dokumentów wypracowano także Etický kodex České asociace orální historie o. s. (w załączniku). 
dzi o wywiady biograficzne. Jak twierdzi czeska badaczka oral history Pavla Frýdlová: „Nie przypadkiem badacze nie udostępniają innym użytkownikom zgromadzonych i opracowanych przez siebie wywiadów biograficznych zbyt często i bez niepokoju. Podstawowym powodem tej ostrożności i powściągliwości jest wielka wrażliwość źródła. Poruszamy się na granicy między odpowiedzialnością wobec narratora, który powierzył nam swoją historię, a oczekiwaniami innych badaczy, użytkowników archiwum czy zbiorów źródeł oral history" "17. W związku z tym niemiecka badaczka Almut Leh daje przeprowadzającym wywiad i badaczom dobrą radę: „Postarajcie się wyobrazić sobie siebie w sytuacji narratora, jak byście się czuli, jakiego stopnia wrażliwości oczekiwalibyście, na jakie warunki byście przystali, czy przeszkadzałoby wam, gdyby z historii waszego życia ktoś wyrwał pewne cytaty, bez kontekstu całej historii życia"18.

Nawet mimo wyżej przedstawionych zastrzeżeń i różnic uważamy, że koegzystencja badacza oral history, dziennikarza i publicysty (dokumentalisty) jest możliwa, a nawet wskazana. Oba światy wzajemnie się potrzebują i pewna forma kooperacji tam, gdzie spełnione są podstawowe wymagania etyczne i profesjonalne, jest, i w przyszłości na pewno będzie, nieunikniona. Mamy przed sobą niełatwe zadanie - możliwie najwierniejszą i niezafałszowaną interpretację, albo dokładniej mówiąc, zrozumienie naszej niedawnej przeszłości.

Chociaż z jednej strony odrzucam jakiekolwiek zaangażowanie polityczne w badaniach naukowych, to doceniam zaangażowanie intelektualne i aktywne poszukiwanie nowych tematów badawczych i uważam, że tego rodzaju zaangażowanie może być w ostatecznym rozrachunku korzystne. Mam tu na myśli choćby przesunięcie naszej uwagi także na badanie tych grup, które były i nadal są pomijane w naszej historiografii - na przykład na tzw. zwykłych ludzi. Bez przywrócenia tych grup do historii interpretacja naszej niedawnej przeszłości, zwrócona szczególnie ku zwycięzcom,

17 Zob. P. Frýdlová, Archivace a další využití interview - zkušenosti a pochybnosti, [w:] Př́běh je základ... a lidé př́běhy potřebují... aneb Teoretické a praktické aspekty orální historie, red. J. Petráš (Sborník příspěvků z konference konané v Jihočeském muzeu v Českých Budějovicích 2009. Jihočeský sborník historický - Supplementum 3), České Budějovice 2010, s. 33.

18 Zob. A. Leh, Forschungsethische Probleme in der Zeitzeugenforschung, „BIOS - Zeitschrift für Biographieforschung und Oral History", R. 13 (200o), z. 1, s. 64-76. 
172 częściowo również ku przegranym, prześladowanym i ofiarom, nadal pozostanie bardzo niepełna i w istocie bardzo niedokładna. Potrzebujemy, nie tylko na polu naukowym, otwartej i niczym nie obciążonej dyskusji o wszystkich kwestiach naszej niedawnej przeszłości, która przecież nie kończy się w $1989 \mathrm{r}$.

Uważam, że ponad dwadzieścia trzy lata to dosyć, aby bez uprzedzeń i w kontekście historycznym przemyśleć swoją przeszłość, za pośrednictwem socjologów, historyków i dziennikarzy. Dla czeskiej oral history jest to niewątpliwie wielkie wyzwanie. 
The article aims to highlight the specific route of Czech oral history in comparison with developed countries, where oral history has been an age-old tradition. Czech oral history, same as oral history in other so called post-communist countries, did not experience that with oral history in 1960 s and 1970s, oral history was totally unknown in the then Czechoslovakia (as well as in other countries of the so called socialist block). In the Czech Republic, oral history was used in the mid-199os for the first time; but it took much more time before it stopped being ignored and criticized. Boom of oral history started in the end of 1990s, same like in South America or South Africa, and of course at the post-communist countries.

An increased interest in oral history, however, also brings along some problems and risks related with this new trend. I will examine some cases of journalistic work which passes itself off as oral history and which is often ideologically motivated. Mastering the method and a good knowledge of the historical context are, in my opinion, essential requirements for a valid historical interpretation, and lack of these can be crucial.
Miroslav Vaněk

Parallels and Intersecting Lines. Czech Oral History in Global Perspective 
